\title{
Fear and Loathing in the Caucasus: Tolstoy's “The Raid” and Russian Journalism
}

\author{
William Mills Todd III and Justin Weir
}

Lev Tolstoy's short work “The Raid: A Volunteer's Story” [“Набег: рассказ волонтера," 1853] marks a key moment in his early career. The story implicitly compares a young man's first experience in battle with the challenges of writing literature, riffing on Tolstoy's own autobiographical methods and underscoring his caustic view of journalism. Although "The Raid" was immediately recognized by his fellow soldiers as a barely concealed autobiographical retelling of Tolstoy's own military experience, modern readers may be puzzled by the apparent flurry of genres in its twelve short chapters-nature descriptions, conte philosophique, and war journalism, in addition to fiction and autobiography. Tolstoy summarizes the simple action of "The Raid" in its main title: the volunteer, a first-person narrator, cannot be dissuaded by his captain, named Khlopov, from joining a raiding party against a Chechen village. ${ }^{1}$ The large, well-armed Russian party takes the village with no resistance, but as the Russians return to the fortress, the Chechens ambush them, fatally wounding a boyish, sentimental Russian officer, Ensign Alanin. Lieutenant Rozenkrantz, a parodically Romantic figure, proves ineffectual, both in battle and in comforting 
his dying comrade. The remaining Russian officers, except for Captain Khlopov, are remarkable only for their frivolously gallant French phrase-making.

When viewed in light of Tolstoy's long career, the story is more like an initial foray against the methods and subjects of contemporary literature that would occupy him for many years. Indeed, the real genius of the story lies in its remarkable account of the gestation of an artistic consciousness developing in response to both philosophical and narrative challenges. The subtitle, "A Volunteer's Story," captures these dimensions as deftly as the main title summarizes what one would conventionally call its action. Taken together, the titles suggest a work neither naïve nor experimental, despite its seeming simplicity and its set pieces (framing nature descriptions, parodies, meditations on abstract themes).

Tolstoy began writing "The Raid" just after he completed Childhood [Детство, 1852], and found himself at the proverbial crossroads of an authorial career. Down one well-trod path was military service and a familiar life; should he choose that path, it would be difficult to extract himself from the military commission he had only recently obtained. ${ }^{2}$ Down the other path was the potential recognition, and possible fame, he might achieve as an author. Here he feared somewhat vainly that he would become just another litterateur, one of the professional journalists whom Tolstoy increasingly despised for their narrow-mindedness and petty squabbles. Today's readers know which path he ultimately chose, of course, but as we reread "The Raid" we can still discern some of the exciting chaos of these early inextricable aesthetic and professional decisions. $^{3}$

The first draft of "The Raid" was written in 1852, while Tolstoy eagerly awaited word that his first publication Childhood had appeared in the prestigious thick journal The Contemporary [Современник]. With Childhood in print, Tolstoy's professional literary ambitions grew, and he resolved to add what would ultimately become "The Raid" to a larger series of sketches of military life in the Caucasus. ${ }^{4}$ The diversity of literary genres one finds in "The Raid” itself is reflected in his plans for this series, which never materialized.

Tolstoy was incensed that Nikolai Nekrasov, the editor of The Contemporary, and the government censor had made changes to Childhood. The experience deepened his disgust for the world of thick journals and made him 
wary, even as he was thrilled to submit another story. On November 27, 1852, he spelled this out in a frank letter to Nekrasov:

Although I have written something, I cannot send it to you now, first, because a certain success of my first work has developed my authorial vanity and I want my next works to be no worse than the previous one, and second because the cuts made by the censor in Childhood have made me rework many words to avoid similar incidents.... I will ask you, dear sir, to promise me with respect to my future writing that, if it pleases you to take it for your journal, you will not change anything at all. I hope that you will not refuse me this. As for me, I repeat my promise to send you the first piece I consider worthy of publication. ${ }^{5}$

Tolstoy was understandably quite proud of the warm reception that greeted Childhood, but he was troubled that his freedom as an author could be impinged upon so recklessly by the censor. And censorship was just one of the exigencies of publication in the major journals.

We speak of "fear and loathing" in part to recognize that Tolstoy was both overly preoccupied with and overly dismissive of the censor and entrepreneurial journalists who were implicated in his early efforts at authorship. He felt the call of journalism no less than other writers of the time, but he felt it differently. We recall that Tolstoy soon resolved to start his own military journal, The Military Gazette [Военньий листок, 1855] but the government denied him permission. ${ }^{6}$ He would later start a pedagogical journal, Iasnaia Poliana [Ясная Поляна], named after his estate, in 1861, drawing on his experience of teaching peasants in the school he set up on the subsequently famous estate. Tolstoy wrote pedagogical articles for this journal and he published twelve issues. Those early years, then, witnessed the beginning of Tolstoy's perennially fraught relationship with publishing institutions. His founding of the Intermediary [Посредник] publishing house toward the end of the nineteenth century shows that his obsession did not diminish over time. "The Raid" must be read in this expansive context; otherwise much of the story loses layers of potential meaning. Questions of identity, independence, bravery, friendship, and so forth, that appear early in the story are broadly philosophical, but they are also grounded in this institutional environment. Gestures toward parody in the story echo Tolstoy's extensive metafictional consideration of the authorial process. 
The very subtitle, "A Volunteer's Story," underscores the notion that freedom, including the author's freedom, if sacrificed, will be sacrificed only for a distinct (and temporary?) purpose. The notion of "volunteer" carries this charge. Indeed, the first chapter of the "The Raid" is consumed by this question and sets up the rest of the story. Although Tolstoy had more first-hand experience of the dangers of war than most, if not all, major nineteenth-century writers, he wrote relatively rarely about war: the Caucasian stories, the three Sevastopol Tales [Севастопольские рассказы, 1855], The Cossacks [Казаки, 1863], War and Peace [Война и мир, 1869], and Hadji Murad [Хаджи Мурат, completed 1904; published 1912]. In these works, especially the second and third, one finds certain common elements emphasized in varying degrees: the "spirit of the army" ["дух войска"] as the phenomenon that decides victory and directs the army, a narrator's or character's disapproving or sarcastic appreciation of any officer with romantic pretensions, the helplessness of the officers in determining the tide of battle, the unostentatious valor of the lower ranks or the exceptional unpretentious officer, the leitmotifs of pain (the wounded on stretchers, missing limbs) and disarray (dirt, dust), the blissful ignorance of the society back in the capital cities, and the limited viewpoint of an often inexperienced observer. To a certain extent, these elements are present in “The Raid.” To an even greater extent, they are present in the drafts of the story but not in the final version, which may suggest that this is much less a war story about a "raid" and much more a narrative about "the story" and "the volunteer."

The elements of war in the story are quickly dispensed with. In revising the story, Tolstoy cut an introduction in which the anonymous first-person narrator expresses his interest in war and a childhood desire for heroism, removed from the end of chapter VI a long impassioned refutation of Russia's casus belli and condemnation of adventurers and career-making officers, eliminated an analysis of the "spirit of the army" from the end of chapter IV, and took out a last view of the officers in the conclusion. The effects attained by several of these changes were brevity and lack of artless repetition-the essence of the discarded introduction, for instance, emerges in the conversation with Captain Khlopov in chapter I. In other instances, ideas were cut that probably could not have been inferred by the volunteer from his contact with man and nature. And the removal of a discussion of the larger Caucasian conflict increases the absurdity of the raid, leaving one to assume that it was conducted to further careers, 
satisfy curiosity, and gain plunder. What little mention of fighting there is reads as a parody of the Caucasian war story, as in the explanation of Rozenkranz's exploits, or functions ironically, as in the looting of the village and the death of Alanin. All in all, these two passages constitute perhaps a fifth of the story.

Etymologically, parody is derived from the Greek words "to sing alongside." Such commentary on the works of fellow writers was a constant feature of European literature throughout the century and a quarter leading up to "The Raid," as works of fiction often competed with each other in being "realistic" by showing their predecessors to have been somehow naïve illusions, as Harry Levin has amply documented. ${ }^{8}$ On the Russian scene, for example, Aleksandr Pushkin's author-narrator "sang along side of" the sentimental Lensky in Eugene Onegin [Евгений Онегин, 1823-31 $]^{9}$ and Mikhail Lermontov's hero Pechorin "sang alongside of" the would-be romantic hero Grushnitsky in A Hero of Our Time [Герой нашего времени, 1840], in which Pechorin boasts: "In me there live two men: one lives in the full sense of that word, the other thinks and judges him." ${ }^{10}$ Pechorin, however, fails to apply the same ruthlessness to himself that he applies to Grushnitsky and, like the Byronic romantic outcast, demands more sympathy for himself than many later readers and parodying writers were willing to grant. Thus Rozenkranz, whose actions in society parallel both Pechorin's (showing off before young ladies) and Grushnitsky's (believing one has enemies), is "sung alongside of" as he is contrasted with Khlopov and deflatingly analyzed by both the volunteer and his own Circassian ("natural") mistress, a case of hoisting Lermontov's hero with Lermontov's petard, the multiple viewpoint. Here the volunteer looks beneath the mask and sees inner contradiction and dim-witted uncertainty (reflected in the terms "something" ["что-то"] and "as if" [“как бы”]):

He often went out at night into the mountains with two or three Tatar allies, in order to lie in wait along the road and kill hostile Tatars who happened to be passing by. Although his heart told him more than once that there was nothing daring in this, he considered himself obliged to make people suffer, people in whom he was disenchanted for something, and whom it was as if he despised or hated. ${ }^{11}$

Rozenkranz's mistress describes him as someone much smaller than his pretentions: "He was the nicest and most humble person ... and every evening he wrote his gloomy notes, kept accounts on graph paper, and prayed to God on his 
knees." ${ }^{12}$ As Eikhenbaum points out, this is hardly the awe in which the paradigmatic romantic heroine holds the romantic hero. ${ }^{13}$

The two little episodes in which Rozenkranz manifests his futility are mock heroic masterpieces: skeleton plots with a central hero and situational clichés, a rescue in the nick of time, and the chivalrous treatment of an enemy. Rozenkranz is punctured, literally, in the latter instance, by a bullet "below the back." 14

The main military action of the novel—the taking of the village — unfolds ironically: there is little resistance; the sole captive taken is a helpless old man; and the loot consists of a rag, a tin basin, two hens, and a white goat. The brief discussion of the skirmish is a prototype of Tolstoy's subsequent battle descriptions: the enemy is unseen from the narrator's viewpoint, the narrator describes the sounds of battle, shells fall impersonally out of the sky, the vain officer strikes poses, the inexperienced officer glows with enthusiasm, the wise officer keeps calm and does not get in his soldiers' way, the soldiers return toward the narrator, bearing the dead and wounded. Amongst the latter in this story is Alanin, the naïve youth who led an unnecessary charge. Neither his fatal wound, nor Rozenkranz's inept remark, nor the doctor's cruel probing produces an epiphany for Alanin-he just feels "surprise and reproach." Northrop Frye provides the perfect nomenclature for such plot development: "irony with little satire is the non-heroic residue of tragedy, centering on a theme of puzzled defeat." 15

It is important to draw this distinction between irony and satire in "The Raid," for satire was what Tolstoy tried to eliminate from the story during the seven months that he was writing it. In other words, Tolstoy edited the story to focus more on literature itself and less on social behavior. One of his final comments on the story was: "I wrote a lot. It seems it will be good, and without satire. ... It is even unpleasant for me to describe the bad sides of a whole class of people." 16 The satiric remainder is the parody of a Caucasian romantic hero, which is quite brief, and various comments, briefer still, on the officers, almost Gogolian in inspiration, if not in cleverness: "The battalion commander, expressing his rank on his fat face, set to eating." ${ }^{17}$ The volunteer's negative evaluation of a German officer was cut, as was a passage in which Khlopov becomes a typical raisonneur of satire: "The captain said that the general's appearance was not merely not majestic but somehow stupid and drunken, and that it was fitting for a Russian general or colonel to be like a Russian soldier, not an English huntsman."18 
"The Raid" is, then, less a work of anti-Romanticism than something else, emerging from a reportorial context. The parallels Eikhenbaum draws with the contemporary genre of the Caucasian military sketch are relevant. They show some of the materials the 1851 issues of The Contemporary set before Tolstoy: "notes," dates, geographical and ethnographical details, a wealth of Caucasian vocabulary, and parodies of romantic descriptions of the Caucasus. ${ }^{19}$ Nevertheless, what Tolstoy finally presents is "The Raid: A Volunteer's Story," not "A Letter from the Caucasus," which was the story's first title. What the change of titles emphasizes is that we are dealing not so much with a bit of factual reportage mixed with various generalizations and comments on the inadequacy of past representations of the subject, as with a story-one that, as we shall see, examines the effects of fellow men and nature on a first-person narrator, who is seen in one magnified stage in the process of maturing. The facets of the Caucasian sketch that enter the story become not the objects of a report but the materials that contribute to this process.

Tolstoy treats the authorial or metaliterary aspect of the narrator's development philosophically. To become a successful author is entwined with becoming a mature and autonomous man. Chapter I introduces the volunteer, who is the first-person narrator, and Captain Khlopov, who informs him about the impending raid and tries to convince him not to participate. The volunteer's character development is opposed to that of Rozenkranz, the romantic hero whose autonomy is undermined by his clichéd behavior and whose masculinity is perhaps cast into doubt by his injury and his Circassian mistress' belittlement. Khlopov serves as both a better model of manhood and a philosophical foil for the volunteer. As we learn later in the chapter, the volunteer's estate is not far from Khlopov's childhood home, and so he is able to describe a visit to Khlopov's mother, who, when learning of the volunteer's destination, asks him to deliver an icon to her son. The simplicity of mother and son and the authenticity of their relationship contrast sharply with the other male-female relationships in the story.

There are both explicit and implicit signs that the volunteer has been dwelling on notions of choice and free will. As in other digressions in early works by Tolstoy, such as the one on "comme ilfaut" in Boyhood [Ompoчеcmвo, 1854] and the one on "truth" in "Sevastopol in December" ["Севастополь в декабре месяце," 1855], in “The Raid,” the narrator reflects on the definition 
of "bravery." Having recalled Plato's definition that bravery distinguishes between what is necessary and what is unnecessary to fear (in the Socratic dialogue the Laches), the narrator inscribes "choice" into the Platonic notion: "Yes, I said, it seems to me that in every danger there is choice, and a choice made under the influence, for example, of duty is bravery, but a choice made under the influence of a base feeling — that is cowardice." ${ }^{20}$ We have here both the young man's callow need to philosophize about everything and his obsession with "measuring up" to his fellow soldiers. He overtly cites free will in his ruminations on bravery. Less overt is his implicit comparison of himself with Khlopov. As a "volunteer" he chooses freely whether or not to put himself in harm's way.

In fact, throughout the entire first chapter, the volunteer works to substantiate both his free will and his difference from others. By contrast, Khlopov repeatedly attempts to categorize the narrator in a way that limits his freedom, by comparing him to other people:

Well, what then? You simply wish, evidently, to see how people are killed? ... In 1832 there was also someone who wasn't serving, Spanish, it seems. He went on two campaigns with us, in some sort of blue cloak... still they did the lad in. Here, old fellow, you won't surprise anyone. ${ }^{21}$

Instead of serving in some capacity, the narrator is accused of merely wanting to watch, a physically passive role but one that is morally reprehensible. (The morality of vision is also the subject of "Sevastopol in December," written just two years after "The Raid.") Note, too, how "volunteer" becomes "one who doesn't serve." In the first paragraphs, the narrator was worried that he would "miss" ["пропустить"] the action. He feared his own absence. Now Khlopov threatens to define him by a similar negativity, by what he does not do-literally "one who does not serve." The narrator takes this attempt to define him and reverses it: rather than one who serves, he becomes one who chooses to serve. He makes an active choice, and a "brave" one, defining himself in the process.

Nothing would seem to be out of the ordinary with a first-person narrator distinguishing himself in this fashion. By creating a unique voice and telling a unique story, first-person narratives in the modern era almost always forge a singular identity. Unusual but significant for “The Raid," the like/unlike binary introduced by Captain Khlopov is tied by Tolstoy to the authorial dynamics of 
the story. After listening to the volunteer describe his choice as the very definition of bravery, Khlopov replies: "Well, I can't prove it to you ... but we have a cadet who also likes to philosophize. You should talk with him. He even writes poetry."22 Rather than the brave and free hero the narrator implies he is, he is likened to a philosophizer and verse writer. Khlopov does not necessarily mean to make a positive comparison, though he plainly deals with the narrator in a sympathetic way. The comparison to a poetry writer is the give-away that we are dealing with a metaliterary passage-Tolstoy reflected on the literary process even in his earliest experiments (e.g., "A History of Yesterday" [“История вчерашнего дня," 1851].

The narrator's first response to Khlopov's attempt to categorize him is in fact to philosophize about bravery. Now he chooses to "write verse" or, rather, to do what prose writers do instead: he tells a story. The remainder of Chapter I is devoted to the narrator's memory of visiting Khlopov's mother. A key moment in this enclosed story is, unsurprisingly, that Khlopov does not write his mother as often as he should. Although the narrator may or may not correctly celebrate Khlopov's bravery, Tolstoy underscores the point that Khlopov would make a bad author.

The authorial themes in the first chapter of the story are implicit, not hidden per se but not obvious either. Whereas Khlopov serves in the army, the narrator is a freely participating volunteer. Whereas Khlopov refuses to respect philosophizing and writing a means of individuation, the narrator endeavors to individuate himself in precisely those ways. The much larger and more obvious literary background created by Lermontov, who is not mentioned, and the military historian Aleksandr Mikhailovsky-Danilov, who is mentioned, sets up the entire chapter, in which the narrator distinguishes his ideas and his authorship as original. Khlopov is a figure against whom the narrator asserts his independence and his irreplaceability. Of course, Khlopov himself is also a model of authenticity in the story, but he is neither the "hero of our time" Pechorin figure of "The Raid" (that would be Rozenkrantz), nor even a typical "hero," since he acts and speaks more modestly. If anything, Khlopov plays the role of Lermontov's Maksim Maksimych, who pointedly fails to comprehend the writerhero Pechorin and who avoids literary and philosophical discussions.

The philosophical questions of choice and free will discussed by the narrator and characters and suggested by the metafiction of the first chapter are closely 
entwined with Tolstoy's authorial concerns in this early period. And authorship at this time generally meant publication in a journal. Tolstoy thought a lot about these matters, even in his earliest fiction. For example, the penultimate chapter in an early draft of Childhood, "To Those Gentlemen Critics Who Care to Consider It," and the final chapter of that manuscript, "To Readers," sketch out Tolstoy's early ideas about authorial process and reader reception. ${ }^{23}$ These chapters were hypothetical for Tolstoy-since he had not yet been published-and he removed them in the final version. His defensive address to the "critics" is thus itself a kind of fiction, and echoes attacks on critics in Nikolai Gogol's Dead Souls [Mepmвые дуии, 1842] and Lermontov's A Hero of Our Time. The difference is that Tolstoy's metafiction is literally separated from its fiction.

In "To Those Critics," the context of the journal is unmistakable. Tolstoy writes:

I embark on a literary career with great reservation and distaste. . . Why? Because you, Dear Gentlemen, are for me those from whom in my literary career I am afraid to receive offense. The word offense I speak here not at all in a metaphoric sense, but in a direct one... When you write criticism ... of all readers you have most in mind the author, and sometimes him alone. ${ }^{24}$

Tolstoy insists on the singular, autonomous activity of the author and the critic and on the personal nature of their relationship. Tolstoy suggests, moreover, that were he to be attacked by critics, there should be no distinction between himself-Count Tolstoy, a nobleman with legal rights and privileges - and his authorial identity. Thus in his peculiar request to eliminate from reviews the use of the editorial first-person plural, "we," Tolstoy hopes, however naïvely, to individualize the critics and to force them each to assume a single responsible identity. A barely submerged threat is contained in Tolstoy's reference to "libel": "To write or say such things about a person that you would not say to his face nor write him means to say offensive things ... means that you are writing libel." ${ }^{25}$ The concept of libel reveals a relationship between the publishing institution and individual action. If it appears that we are digging too deeply for allusions to contemporary journalism in "The Raid," it is only because Tolstoy himself was intent on forcing an institutional relationship into an interpersonal one. 
As is well known, Tolstoy's vision of readership is similarly individuated. In "To Readers," he says: "Any author — in the broadest sense of that word—when writing whatever, invariably imagines what effect his writing will have. When the entire work pleases one person, then that work, in my opinion, is perfect in some sense."26 The idea of writing for a single reader stuck with Tolstoy-one can even imagine that the idea of aesthetic "infection" from his late essay What is Art? [Что такое искусство?, 1897] derives, in part, from his notions of the intimacy of aesthetic reception. With What is Art? in mind, G. N. Ishchuk cleverly remarks: "By the way, it is not difficult to guess that [Tolstoy's] 'imaginary reader' looks very much like the young Tolstoy himself." first, as we have said, to address critics and readers. Most important is that in his literary attempts to define himself he uses (real or imagined) institutional resistance in the creative appropriation of his authorial identity.

Despite the obvious differences between Childhood and "The Raid," they share a number of common structural elements and share them with much of Tolstoy's subsequent writings: contact with a preceptor, with society, with nature perceived by almost all the senses and in great detail; presentation of characters and scenes in contrasting pairs; the journey to link episodes, and provide different viewpoints for the narrator. This similarity of Tolstoy's narratives throughout his sixty-year writing career can hardly escape notice. Most of these structural elements are invariably present, even if only as underdeveloped nuclei. The major character undergoes a mental journey from stage to stage; in the novels or in Confession [Исповедь, 1880], that journey has many such stages. Sometimes this mental journey occurs on an ironic plane, as in The Cossacks. In most of the works, the intellectual journey is accomplished on a path (in all seasons, in lines or circles, by coach, horse, train, raft, or foot) along which or at the end of which the traveler changes his opinions, beliefs, or understanding. Such a path is a device Tolstoy probably learned from Laurence Sterne's A Sentimental Journey [1768], but also one which is perfectly melded to his conception of his protagonists as intellectually restless seekers. Indeed, with reference to "The Raid," Tolstoy's statement that he learned all about war from Stendhal is something of a red herring. The sort of mind that would pay articulate attention to its own sensations in the midst of a battle is less that of the ironically treated Fabrice del Dongo at Waterloo and more that of Yorick, who did not give the war between France and England much consideration in A Sentimental Journey. ${ }^{28}$ 
The volunteer's journey in "The Raid" is intellectual, as he goes through at least a dozen definitions of bravery. He offers the first six in chapter I, a dialogue (somewhat Socratic, although Khlopov's midwifery is passive). ${ }^{29}$ The volunteer seems to start from the usual dictionary definition of "bravery" ["храбрость"] - "the absence of fear when in danger." 30 This is discernable from the fact that he has been waiting a month to see some action and regards as brave a Spaniard who rushed into the thick of battle in bright apparel ${ }^{31}$ From here the volunteer takes two of the captain's definitions (it is not brave to push in where one is not ordered, and bravery consists in behaving as one should), reconciles them with Plato's definition (bravery is the knowledge of what one should and should not fear), and arrives eventually at the following synthesis, which is not at all close to his implied definition from the story's previous page:

It seems to me that in any dangerous situation there is a choice, and a choice made under the influence, for example, of a sense of duty shows bravery, while a choice made under the influence of a base feeling shows cowardice. A man, therefore, who risks his life out of vanity, or curiosity, or cupidity cannot be called brave, and, conversely, a man who turns away from danger under the influence of an honorable feeling of family obligation or simply conviction cannot be called a coward. ${ }^{32}$

A fascinating psychological process is taking place here. The speed with which the volunteer changes definitions reveals the extent to which he feels guilty about his initial attitude, wanting to see people killed, as the captain puts it, and realizes his similarity to the Spaniard. The volunteer barely mentions his discomfort: "No matter how ashamed I felt that the captain had so stupidly interpreted my intentions, I did not try to dissuade him." Consequently this long definition becomes another generalization motivated by the emotional state of the narrator. ${ }^{33}$

It is motivated as well by the volunteer's admiration for Captain Khlopov, which emerges from the first two chapters. He depicts Khlopov as a low mimetic saint in the mold of Childhood's Natalya Savishna. The hagiography isolates them from the normal activities of earthly existence: Natalya gives up marriage to serve her masters while Khlopov does not play cards, carouses rarely, and smokes only cheap tobacco. Khlopov's saintly image is drawn to the needs of "The Raid"; the volunteer attributes to him a "simple, calm, Russian physiognomy" and little that is military or beautiful. ${ }^{34}$ His values match his unprepossessing 
appearance when he shows indifference to the thrill of the campaign or of the hunt. He links these two activities, the hunt and military pursuits, by suggesting that the volunteer go hunting instead of taking part in a raid. ${ }^{35}$ The volunteer's vita includes a passage in which Khlopov ignores a rising pheasant that would have gladdened the heart of any hunter. ${ }^{36}$

Next encountered along the volunteer's journey are Alanin and his implicit mentor Rozenkranz, presented in contrast to the volunteer-Khlopov pair. Alanin, like the volunteer at the beginning of the story, is "young," as the gruff captain says. The whole episode of Alanin's death within the thematic structure of the story is subordinate to the discussion of bravery, which is concluded at the end of Chapter X, and to the contrast between Khlopov and Rozenkranz. The description of Rozenkranz at the beginning of chapter IV is almost an exact antithesis to that of Khlopov at the beginning of chapter II: Rozenkranz lives with his dagger on, has four kinds of braid, five weapons, a large white horse, and a most un-Russian name (despite his protestations of ancient Varangian descent). Its Shakespearean reverberations reinforce Rozenkranz's fatuous foppery. Just as Alanin will follow Rozenkranz in mock heroism, rescuing a goat instead of two pigeons in the nick of time, and in excited behavior before battle, so will the volunteer come to imitate Khlopov's views on military enthusiasm, calling an adjutant who wants to go to battle in chapter $\mathrm{V}$ a "child," and professing to understand nothing, thus forgetting that enthusiasm and curiosity had been his own attitudes of the day before, just as he makes no comparison between the scribbling Rozenkranz and himself.

The definitions and examples of bravery in chapter II are those of the regiment: officers who abuse their horses on a hot, dusty day and Rozenkranz's posturing.

The subsequent important treatment of bravery occurs in chapter $\mathrm{X}$-it marks the zenith of the volunteer's imitation of Khlopov, who is called "truly brave" for being himself, as always, before the skirmish. Next comes the final definition of bravery, whose seed was sewn in the captain's disapproval of the Spaniard in chapter I. That seed grew in the comparison of the two villagesthe fort with its French-speaking officers and German music, both of which distress the volunteer; and the clean, lovely Caucasian village, which the greedy (ergo uncourageous) soldiers destroy. Then comes the ostentatious conversation in French between the two officers in chapter IX. All of this inspires the last 
definition of bravery: Russian bravery requires performing great deeds without lofty phrases. Echoing Khlopov's theme of "youth," the volunteer adds sententiously: "How can a Russian heart not feel pain when it hears vulgar French phrases from our young warriors, who have pretentions of imitating antiquated French knights?"37

It even turns out that the truly brave captain was afraid during battle, and thus was the dictionary definition completely reversed, as so often happens in Tolstoy, who in an ultimate tour de force would define away death in On Life [O жизни, 1887.]

"Vulgar French phrases" is a formulation that suggests an antithesis of Tolstoy's aesthetics, which aim for communicative efficiency and reject the superfluous and needlessly ornate. Like other early stories by Tolstoy, the narrative of "The Raid" meanders (à la Sterne) but does not dwell on the superfluous. After the village is destroyed, for example, the volunteer remarks:

The sight was truly magnificent. However, for me as one who had not taken part in the action and was unaccustomed, the impression was in general spoiled. Something seemed superfluous to me-that movement and the animation and the shouting. A comparison involuntarily occurred to me of a man swinging his arms as though to cut the air with an axe. ${ }^{38}$

While describing the superfluous behavior, however, the narrator still makes use of a striking metaphor, the axe, which occurs to him against his will-so perhaps the episode is not entirely without utility. The image of the writer revealed in "The Raid" rests on similar balancing acts of irony, as the narrator cites authorial or journalistic conventions only in order to announce how he will overcome them.

"The Raid" ends not, as was originally intended, with the various officers striking characteristic poses, but with the volunteer engrossed in perceiving nature and hearing the strong, sensitive voice of the regimental tenor, just as he had been engrossed in perception two days before he set out. This is a fitting last example of how "The Raid" is less a parody, a war story, or a Caucasian sketch, than a story of a mind undergoing a stage in its development in reaction to a variety of phenomenacontrasting characters, contrasting surroundings, contradictory definitions, and the disharmony of war and nature. Tolstoy's writerly mind dwelled irrationally on the fear of having his independent motives wrongly interpreted, but simultaneously 
loathed being beholden to a journalistic institution that could give him a public voice. This insistence on the perceptions of a mind in action concludes not only the ostensible plot of the story, but also the plot of authorial development.

\section{Endnotes}

1 On the autobiographical material in "The Raid" and on its contemporary reception, see N. I. Burnasheva, 303-308, 310-14. Quotations of Tolstoy's works in this essay, unless otherwise noted, come from one of two sources: the as yet incomplete online Полное собрание сочинений [Complete Collected Works] in 100 volumes, hereafter cited by volume and page number in parentheses, or the older Полное собрание сочинений in 90 volumes, hereafter cited as Chertkov edition, followed by volume and page number in parentheses. All translations are William Mills Todd III's.

2 Burnasheva, “Произведения,” 288-89.

3 Orwin, Consequences of Consciousness, 60-61.

4 Burnasheva, “Произведения,” 287-88.

5 Quoted in Burnasheva, “Произведения,” 288.

6 See N. N. Gusev, 47. In an 1858 letter to V. B. Botkin Tolstoy proposed a journal devoted to purely artistic, versus political, works and subjects. The journal was never realized. See Šilbajoris, 21-22.

7 Gusev, Летопись жизни, 129; Biriukov, Биография Л. Н. Толстого, I:241-68.

8 Levin, Gates of Horn, 39-48.

9 Pushkin, Eugene Onegin, VI:21-22.

10 Lermontov, A Hero of our Time, “Princess Mary,” June 16.

11 Tolstoi, $\Pi C C$, online edition, 2:13.

12 Ibid.

13 Eikhenbaum, Молодой Толстой, 94.

14 Tolstoi, $\Pi C C$, online edition, 2:14.

15 Frye, Anatomy of Criticism, 224.

16 Tolstoi, $\Pi C C$, Chertkov edition, 3:292.

17 Tolstoi, $\Pi C C$, online edition, 2:14. E. N. Kupreianova notes that both "The Raid" and the incipient "Novel About a Russian Landowner" included satire of a Gogolian nature, but that Tolstoy pruned the satire for the final 
versions (66). Nevertheless, a few Natural School touches do remain: the ludicrous icon of Khlopov's mother, the various "homunculi" (Nabokov's, not Sterne's, meaning) in chapter V, the non-heroic activities of the officers in chapter IV, the characterization of dress as extravagant throughout.

18 Tolstoi, $\Pi C C$, Chertkov edition, 3:219-20.

19 Eikhenbaum, Лев Толстой, 131-36.

20 Tolstoi, $\Pi C C$, online edition, 2:8.

21 Ibid.

22 Ibid., 2:9.

23 These essays are treated more fully in Weir, 42-49.

24 Tolstoi, $\Pi C C$, online edition, 19:137, ellipses ours.

25 Tolstoi, $\Pi С С$, online edition, 19:137.

26 Ibid., 19:141.

27 Ishchuk, Проблема читателя, 20.

28 The treatment of Tolstoy and Stendhal in Eikhenbaum, Молодой Толстой, 95-100, is in general more useful for later descriptions of war, since the volunteer has ceased to be an enthusiastic novice from the second page of "The Raid." Furthermore Eikhenbaum's equation of their "business-like, inelegant styles" ignores the difference between Tolstoy's frequently rhetorical, all-inclusive sentences and Stendhal's generally jerky "Code Napoléon" style.

29 Bursov notes that Tolstoy had been reading Plato just before writing "The Raid" (180).

30 Standard nineteenth-century (Dal') and twentieth-century (Ushakov, Ozhegov) offer this as a primary definition. The English "bravery," which usually translates "храбрость," is broader in meaning, incorporating appearance and bravado, as the Russian term does not.

31 Tolstoi, $\Pi C C$, online edition, 2:8.

32 Ibid., 2:9.

33 Ibid., 2:8.

34 Ibid., 2:10.

35 Ibid., 2:8.

36 Ibid., 2:11.

37 Ibid., 2:28.

38 Ibid., 2:23. 


\section{Works Cited}

Biriukov, Pavel. Биография Л. Н. Толстого: В двух книгах. 2 Vols. Moscow: Algoritm, 2000.

Burnasheva, N. I. “Произведения 1852-1856 гг.” In L. N. Tolstoi, Полное собрание сочинений в 100 томах, 283-567. Moscow: Nauka, 2000-.

Bursov, B. I. Лев Толстой. Идейные искания и творческий метод, 1847-1862. Moscow: Goslitizdat, 1960.

Eikhenbaum, Boris. Молодой Толстой. Petersburg/Berlin: Izdatel'stvo Z. I. Grzhebina, 1922. . Лев Толстой. Vol. 1. Moscow-Leningrad: 1928.

Frye, Northrop. Anatomy of Criticism. New York: Atheneum, 1966.

Gusev, N. N. Летопись жизни и творчества Л. Н. Толстого. Moscow: Academia, 1936.

Ishchuk, G. N. Проблема читателя в творческом сознании Л. Н. Толстого. Kalinin: Kalininskii gosudarstvennii universitet, 1975.

Kupreianova, Е. N. Молодой Толстой. Tula: Tulskoe knizhnoe izdatel'stvo, 1956.

Levin, Harry. The Gates of Horn: A Study of Five French Realists. London: Oxford University Press, 1966.

Orwin, Donna Tussing. Consequences of Consciousness: Turgenev, Dostoevsky, Tolstoy. Stanford: Stanford University Press, 2007.

Šilbajoris, Rimvydas. Tolstoy's Aesthetics and his Art. Columbus: Slavica, 1990.

Tolstoi, Lev. Полное собрание сочинений. 90 vols. Edited by V. G. Chertkov et al. Moscow: Gosudarstvennoe izdatel'stvo "Khudozhestvennaia literatura," 1928-1958. . Полное собрание сочинений в 100 томах. Moscow: Nauka, 2000-.

Weir, Justin. Leo Tolstoy and the Alibi of Narrative. New Haven: Yale University Press, 2011. 
